How to cite this article:

Salim, S., Abd Halim, N, Syed Adnan, S. N. I., Mat Zin, S. F., Nik Din, N. N. F. \& Yaacob, A. (2020). ESL rural primary students' performance and perceptions of learning English vocabulary through games. Practitioner Research, 2, 1-24.

\title{
ESL RURAL PRIMARY STUDENTS' PERFORMANCE AND PERCEPTIONS OF LEARNING ENGLISH VOCABULARY THROUGH GAMES
}

\author{
*Sulaihah Salim ${ }^{1}$, Nisha Abd Halim², Sharifah Nurul Izati Syed \\ Adnan $^{3}$, Siti Fatimah Mat Zin ${ }^{4}$ Nik Nur Fathiha Nik Din ${ }^{5}$ \& \\ Aizan Yaacob ${ }^{6}$ \\ ${ }^{123456}$ School of Education and Modern Languages \\ Universiti Utara Malaysia \\ *Corresponding author:* ohsufai@gmail.com
}

Received: 05/04/2020 Revised: 20/07/2020 Accepted: 03/08/2020 Published: 03/08/2020

\begin{abstract}
This action research investigated the use of games to boost ESL rural primary pupils' motivation to learn English vocabulary. 18 Year 6 pupils from a rural school in Gua Musang Kelantan were selected by using convenient sampling. Multiple methods such as pre-test, post-test, observation, and interviews with teachers and pupils were used for data collection. This paper highlighted pupils'voices of the effectiveness of vocabulary learning as the result of the pre and posttest showed a significant difference in which pupils have acquired the new words effectively and there was an improvement after having a game-based lesson. The findings indicated that the pupils showed significant improvement in their vocabulary scores after using games. Students reported that learning vocabulary by using games was fun and interesting, as it increased their motivation to learn the English language, helped them to memorise the vocabulary items faster, and increased their interaction in class. Furthermore, the competitive and repetitive nature of the game helped in vocabulary retention.
\end{abstract}

Keywords: games, songs, motivation, rural areas, L2 vocabulary, ELT. 


\section{INTRODUCTION}

One of the most important issues in second language teaching is vocabulary instruction and perhaps one of the most difficult aspects of learning a second language is the retention of learned vocabularies (Holden, 1999). In the lower primary Malaysian school context, vocabulary acquisition is an important part of second language learning and is emphasized in the syllabus as stated by Ismail, Zaid, Mohamed and Rouyan, 2017. The importance of vocabulary is widely researched. Harmer (1991) claims that "If language structure makes up the skeleton of language, then it is vocabulary that provides the vital organs and flesh," (1991, p. 153). ESL pupils must acquire good vocabulary knowledge to enable them to understand and communicate in English. However, barriers such as environment, exposure to the target language, and facilities seem to prevent ESL pupils from acquiring good vocabulary.

According to Hatch and Brown (1995), there are numerous types of approaches, techniques, exercises, and practice that can be used to teach vocabulary, however, teachers should decide what would be best for the students and their circumstances. In this regard, Rivers (1981) mentioned, "as language teachers, we must arouse interest in words with a certain excitement in personal development in this area...we can help our students by giving them ideas on how to learn vocabulary and some guide on what to learn" (p.463). While there are many approaches and techniques available for teaching vocabulary to young learners, the traditional methods are still widely practiced in rural schools. Nguyen and Khuat (2003) and Uberman (1998) argued that students are tired of learning vocabulary in traditional methods such as rehearsing, writing words on papers or learning passively through a teacher's explanation. Nguyen and Khuat (2003) discovered that students prefer to learn a language in a relaxed environment such as using vocabulary games. Learners enjoy language games because they enjoy communicative involvement with their peers in the classroom (Larsen-Freeman, 1986). He believes that games can provide healthy and constructive competition, can encourage learners' discovery and voluntary involvement in the learning process and it can also establish a better bonding between teacher and learners. Thus, this paper examined the use of games in learning English 
among primary ESL students, with limited English proficiency in a remote area in Kelantan. Specifically, it highlighted students' voices [ZIZ6] in their language learning process.

\section{Problem Statement}

Teaching English to ESL learners in rural schools is a very challenging but rewarding job because they neither have the English environment nor the language ability to communicate in English. They only learn English at school and seldom use the language outside the classroom. Most of them could not master the language well (Esterman \& Hedlund, 1995; Smith, Beaulieu \& Seraphine,1995) due to their limited English proficiency. Concerning this, teachers not only need to help them to learn English but also need to create a fun learning environment in the classroom. Fun games, activities, team tasks, and real situations not only get students speaking, but also make learning interesting and enjoyable. At the same time, this fun learning environment can reduce students' anxiety in language learning, thus, making the acquisition of input more likely (Richard \& Amato, 1998: p. 147).

Games in language learning have been extensively studied and many researchers reported the benefits of games for language learning (Larsen-Freeman, 1986; Richard-Amato, 1998; Taheri, 2014; Nguyen \& Khuat, 2003; Parveen, Mehmood \& Khan 2016). According to Larsen-Freeman (1986), as cited in Coady \& Huckins (1997), language games have real-life communication features because the players are required to exchange ideas with each other and they will also have the opportunity to receive immediate feedback from their playmates and their teachers. In other words, games can be challenging yet motivating. On the other hand, Hansen (1994) mentioned one of the advantages of the language game is that it provides an opportunity for shy students to volunteer in classroom activities. Shy and timid students who do not show any tendency to participate in class works will feel more at ease and will participate more freely during games. While many studies on games focused on students' achievement using quantitative analysis, very few studies focused on capturing rural students' perspectives on their learning using action research. Therefore, more studies are needed to examine learners' voices to understand the issue under study. 


\section{Research Objectives:}

This study attempted to answer the following questions:

1. How do games boost the pupils' motivation to learn English vocabulary?

2. Do games help the pupils to improve English vocabulary?

\section{LITERATURE REVIEW}

The acquisition of vocabulary depends not only on how learners learn but also on how they are taught (Tengku Mohamad Maasum, Mustafa \& Stapa, 2015). Earlier studies have also mentioned the importance of creating a motivational climate in vocabulary learning (Lightbrown and Spada, 1999; Moon, 2000; Nguyen and Khuat, 2003). Lightbrown and Spada (1999) stress the importance of motivation and emphasize that "the principal way that teachers can influence learners' motivation is by making the classroom a supportive environment in which students are stimulated, (and) engaged in (the) activities" (p.163). Motivated learners have, however, a better chance of learning vocabulary successfully while the unmotivated ones will have a lesser chance of success. Thus, to enhance learners' vocabulary, they need to be motivated by playing a game to complete the task, and with the enjoyment achieved, learning the lexis occurs smoothly (Moon, 2000). In other words, learning new vocabulary through enjoyable and out of the ordinary ways may assist the learners to learn vocabulary. Learning vocabulary through games allow pupils to enhance connection and collaboration between group members and provide information on how the games made them more engaged and enhanced the learning process (Fitri Mohamad, Morini, Minoi \& Arnab, 2018).

Besides games, songs are also another technique that can be considered entertaining to young learners. The best learning happens when pupils have fun. Since children were small, they were exposed to music and songs in their homes and community. Earlier studies have indicated that song is one of the alternative ways to increase English vocabulary (Burhayani, 2013; Gasma, Yufrizal \& Sukirlan, 2016, Kuśnierek, A, 2016; Dzanic \& Pejic, 2016). According to Šišková (2008), music has always played a big part of humans' lives, beginning with a child's 
birth and mothers singing lullabies to their children. Wrenshall claimed that "there is also plenty of evidence that songs help memorization, and the rhythm and rhyme of the lyrics can certainly help vocabulary as well". Students learn by repeating the rhymes of the lyrics and they gain the opportunity to enrich their vocabulary by vocalizing the language. Gasma et al. (2016) noted in her research that the use of English songs can improve the quality of vocabulary in teaching and learning processes. This happened because songs can stimulate them to acquire the new words that they listened to. In this study, the researchers have included some songs as part of the games to stimulate their vocabulary learning.

Children have a shorter attention span than adults. Hence, the teacher needs to be creative in delivering the contents of the lesson for longer memory retention. It is believed that by introducing songs, students might be able to remember the words learned easier. Moreover, songs help them to enjoy the learning process and easily remember new words. Singing the song and doing the actions help students to know and understand the lyrics or the new words without asking another person or looking them up in the dictionary. According to Dzanic and Pejic (2016), songs are highly motivational because they increase understanding, inspire, and motivate students to learn, making the act of learning fun. They postulated that the motivation of young foreign language learners needs to be built gradually, making sure that the target structures are introduced in an easily attainable order. They also mentioned that during this process teachers should be realistic about each student's abilities. Teachers also need to vary the group dynamics and support the development of social interaction within the group. As such, to maintain positive motivation, the use of songs should be planned in advance.

\section{Theoretical Underpinning}

Cooperative Learning is a part of group teaching and learning techniques where students interact with each other to acquire and practise the elements of a subject matter and to meet common learning goals. It is much more than just putting students into groups and hoping for the best (Macpherson, 2015). It requires the teachers to stimulate the students' thinking skills collaboratively so that they can discover 
the learning process together. At the same time, students need to have problem solving skills too. Games are normally associated with cooperative learning. The elements of friendly competition in games can be motivational for students. In order to create an awareness of enduring cooperative learning among the students, the teacher needs to highlight the advantages and benefits that they will earn. For instance, they will learn to be responsible for what they decided as noted by Macpherson (2015) that in cooperative learning teams positive interdependence is structured into the group task activities and members are responsible for each other's success. Earlier studies have found that learners who were involved in cooperative learning activities developed skills for interpersonal communications more readily than learners who were in other classroom settings did. They were more considerate of others' feelings, worked in cross-cultural situations more easily, liked their classmates and liked their teachers more than other learners. Capar \& Tarim (2015) also stated in their research that cooperative learning is reported to be a more successful method than the traditional method with regard to both achievements and attitudes. In the context of this study, students were engaged in cooperative learning through the game task.

\section{METHODOLOGY}

\section{Research Design}

A research design provides a framework for data collection to answer the research questions. This study adopted a collaborative Action Research design which comprised a series of cycles involving planning, observing, reflecting, and implementing action. The process continued until the intended objectives were achieved. For this action research project, Mill's Dialectic Action Research Spiral (2000) was used as the guideline to plan and implement the actions. Observing 'poor English learning achievement' and having a lack of facilities in the school, this action research aimed to find an alternative interesting teaching strategy to boost pupils' motivation to learn English vocabulary. Therefore, this action research played a vital role to help the teacher assess the effectiveness of the planned strategy for teaching vocabulary and ultimately improve student learning. 


\section{Selection of study site and participants}

The school and the participants were selected based on convenient sampling (Creswell, 2013). Convenience sampling represents sites or individuals from which the researcher can access and easily collect data (p.157). The study took place at SKB, located in a rural area in Gua Musang, Kelantan. One of the researchers was teaching at this school. It is located 192 kilometers from Kota Bharu and around 50 kilometers from Gua Musang. The village is surrounded by hills and river and the only mode of transportation to the town is by train. People use the Kelantanese dialect as their daily language of communication. It is a remote area which only has a train as public transport. Most of the children's parents work as rubber tappers, farmers, and fishermen. Even some of the pupils are left with grandparents or relatives in this village because the parents either passed away or work far away in the city. 18 Year 6 (aged 12 years old) pupils participated in this study. However, four students were selected for the interview. They have limited ability in the English language. Table 1 below shows the profile of the participants.

Table 1

\section{Profile of the participants}

\begin{tabular}{llccc}
\hline No & Name & Age & Gender & Proficiency \\
\hline 1 & Pupil 1 & 12 & F & Low \\
2 & Pupil 2 & 12 & M & Low \\
3 & Pupil 3 & 12 & F & Low \\
4 & Pupil 4 & 12 & F & Low \\
\hline
\end{tabular}

\section{Data Collection Methods}

Multiple methods such as pre-test, post-test, interview, and observation were used in this study. The content of the pre-test and post-test were similar. Each test consisted of 10 pictures (vegetables). During the pre-test and post-test teacher distributed the worksheet and asked pupils to match the names of vegetables to the pictures and their scores were recorded. 1 mark was awarded for every correct answer and the 
total marks were 10. After the post-test, the teacher conducted the interviews with four pupils and two English teachers. The purpose of the interview was to examine their perspectives on the use of games in vocabulary learning. Throughout the action research, the researchers observed the verbal and nonverbal responses among the pupils and the language they used during the interaction. Researchers also reflected on the implementation of all the cycles and did some improvisation for the following cycle.

\section{Data Collection Procedures}

In evaluating the effect of the use of games on ESL students' vocabulary, four cycles of collecting information and analysis were involved in a duration of 2 months. The first cycle involved in determining the problem encountered by the student in the classroom. The problem identification was done through observations of students' activities and vocabulary pre-test. This was to assess the vocabulary level of the students so that necessary actions for improvement could be designed. For Cycle 1, the teacher carried out the pre-test before conducting the Stepping stones game. Based on the pre-test collected it was confirmed that students have lower levels of vocabulary scores. In the second cycle, pupils were introduced to the game. Stepping stones game was a game whereby the pupils needed to move from one station to another to complete the vocabulary tasks. The pupils needed to use the bricks as the tools to reach the station. They took turns going to Station A using two pieces of paper. At Station A, they took a picture card each and returned to their groups. After that, they moved to Station B where they read and answered the riddle. Then, they matched the picture cards to the word cards. In Cycle 3 they were introduced to the stepping stones game again, whereby the teacher added 2 songs "What can you do" and "When I wake up" in the classroom as the improvisation. The teacher played songs. Pupils listened and watched the video. Later, they listened, sang the songs, and acted out. Then, the teacher asked the pupils to list 11 verbs that they heard from the songs. Before the game started, the teacher divided the pupils into groups by asking them to play a 'poison box' game to draw lots. After that, the teacher briefed about the activity where each member of the group would take turns to step on the bricks to reach Station A. At Station A, the pupils had to take 
a picture then hopped back to Station B. When they reached Station B, they had to think of a suitable vocabulary to explain the action in the picture before completing the Giant Word Search. The game rule was that the pupils could only step on the bricks and not on the grass. In this action research, peer assessment was used where Group 1 would assess group 3, and group 3 would assess group 2. [ZIZ12] Peer assessment was used in this cycle as an alternative assessment as well as giving opportunity for the pupils to learn from their peers' work. Finally, they constructed simple sentences for each verb they have collected at Station C. In Cycle 4, the post-test was conducted to assess the vocabulary scores after the game was introduced, and a few students were interviewed to investigate their perceptions on the effect of games on their vocabulary learning.

\section{Trustworthiness}

'Methodological Triangulation' or mixed-methods research which uses more than one kind of method to study a phenomenon (Risjord, Moloney, \& Dunbar 2001, Casey \& Murphy 2009) was adopted to ensure the trustworthiness of the data. For this action research, two approaches were adopted which were qualitative and quantitative. Qualitative research involves the studying of qualitative data such as interview transcripts, observation notes to reveal meanings. Meanwhile, quantitative methods include statistical analysis of outcomes or questionnaires, collected by standardized scales or measures, and expressed numerically (Risjord et al 2001). In this context of the study, pre-test [ZIZ13] and post-test vocabulary scores were analysed. Interviews and observation were also recorded, transcribed, and analyzed using 'thematic analysis' (Braun and Clarke, 2013).

\section{FINDINGS}

This study was conducted to examine the use of games for vocabulary learning. It was based on the following two research questions: How do games boost the pupils' motivation to learn English vocabulary? Do games help the pupils to improve their English vocabulary? This paper reported the students' perspectives on their experiences engaging in games to enhance their English vocabulary. Data were analysed 
using thematic analysis. There were four themes that emerged from the findings: Games enhanced pupils' motivation; helped pupils to memorise the words (vocabulary); increased pupils' interaction and created friendly competitions among them.

\section{Games enhanced pupils' motivation}

The findings indicated that games can boost pupils' motivation. The games were fun and interesting, the pupils were motivated to learn, and they enjoyed the outdoor activity. During the interview, the pupils were asked about the use of stepping stones games in the vocabulary lesson. All four pupils (100\%) admitted that the use of games increased their interest in learning the English vocabulary as they found it to be interesting and fun. The students said it was great, fun, and interesting as illustrated in the extracts below:

Interesting. (Pupil 1)

Best sangat $<$ It is great $>$ (Pupil 2)

Saya suke $<$ I like it $>$ (Pupil 3)

I think...fun (Pupil 4)

Best.. (Pupil 1)

Best..kito suko sebab tok puah $<$ we did not feel bored $>$ (Pupil 2)

Best..sero nok blaja lagi $<$ I feel like wanting to learn more $>$ (Pupil 3)

Ho $<$ yes $>$ best (Pupil 4)

As can be seen in the extracts above, Pupil 2 reported that he did not feel bored to learn while Pupil 3 claimed that he felt like wanting to learn more.

With regards to the use of songs in a certain part of the games, all $(100 \%)$ of the respondents agreed that the stepping stone game and the songs used were also interesting and could attract students' attention. All of them liked the song and some liked both the song and the game played. They said,

Interesting...I like the song and the game (Pupil A)

Emm..game tu..emm best..lagu pon sedak. <the game is best...the song is good too $>\quad$ (Pupil B) 
Best..sedak main $<$ Best...I love it $>$ (Pupil C)

Best..suko main nga nyanyi. $<$ Best..I love to play and sing $>$ (Pupil D)

Meanwhile, the two teachers stated that they agreed with the statement that games are helpful and useful tools in teaching vocabulary to the pupils. From their answers, it was found that both teachers realized that the use of games in language classrooms is an effective tool as the pupils or language learners can participate actively and freely (Teacher 1) throughout the lesson and the pupils were exposed to the fun way of learning English (Teacher 2). They mentioned,

Yes, I agree that teaching vocabulary using games is helpful and useful as the pupils participate actively and freely (Teacher 1) Yes, I agree with that. I think using games to teach vocabulary is fun and helpful

because the pupils are exposed to the fun way of learning vocabulary. They enjoyed

it so much. (Teacher 2)

Besides, they reported that students were enjoying themselves throughout the game in a less stressful manner. Teacher 1 said that her students were less stressful learning English through games as compared to formal classroom teaching. Teacher 2 on the other hand, stated that students were motivated because there was an element of competitiveness and students were playing in a relaxing manner.

Of course. I totally agree with this. I can see that they are enjoying themselves in the game and they are motivated to learn new vocabs because it is less stress compared to formal class (Teacher 1)

Yes, of course. Games help them boosting up their motivation to learn as it has the elements of competitiveness, relaxing and enjoyable (Teacher 2)

when I use games in vocab class, I can say that my pupils are paying full attention in the class. (Teacher A)

Both of them agreed that singing songs in the Stepping Stones Game managed to boost students' motivation to learn English. 
By integrating songs in the stepping stones game, I can see that the pupils are more motivated to learn." (Teacher A)

When we teach vocabulary using games, I can see that the students are more motivated to learn. (Teacher B)

All in all, the interview findings revealed that games helped the students to feel motivated to learn English vocabulary better. All four of them stated that they enjoyed using games in learning English. For rural pupils, English is considered as one of the most difficult subjects to learn due to their limited vocabularies to construct English sentences and what more to use the language. However, it was found that after games were introduced, they became more motivated to learn the language because it was conducted in a fun way outside the classroom environment. As for the teachers, both responded that games could motivate the pupils in learning English vocabulary. Both teachers realized that by using games, the students felt more motivated to learn the language. They also stated that by using games and adding singing activity in the games, their pupils felt less stressed as compared to the formal class and due to elements of competitiveness, relaxation and enjoyment, their pupils were more motivated to learn the new vocabularies.

Some respondents mentioned that learning English vocabulary via games motivated them as they were able to remember the words easily which eventually helped them to complete the giant word search and formed simple sentences. Pupil A mentioned that he wanted to play again, while Pupil B claimed that it was good because she could easily remember the word. Pupil D on the other hand reported that he could compete with other groups to see who was faster and he felt so excited to get all the answers correct. They reported,

Best..sero nok main lagi $<$ Good..I feel like wanting to play again $>$ (Pupil A)

Best..best sebab jadi sene ingat $<$ Good because I can easily remember $>$ (Pupil B)

buleh tanding nga kumpule lain, badi cepat...kito betul blako plok tuh.<can compete with other groups to see who is faster and we managed to get all correct> (Pupil D) 


\section{Outdoor Activity}

Using games outside the pupils' classroom also helped in motivating the pupils to learn English vocabulary better. The pupils were asked whether they liked playing games, and two of the pupils responded that they liked the idea because they could play outside the classroom. This proved that varying instructional methods and bringing the pupils outside their classroom have a positive effect on language learning as it could increase their motivation to learn. Changing the environment for the pupils can become a good thing for the pupils. Pupil 2 stated that he liked to learn outside the classroom because he was never bored learning in that environment whereas he felt sleepy learning inside the classroom. They mentioned,

sedak sangat sebab buleh blajar luar kelah...sokmo blaja dale kelah jah <it is really good because we can be outside the classroom. Normally we only leant inside the classroom> (Pupil 1)

kito suko sb tok puah..kalu dale kelah gak ngatuk la $<$ we enjoyed it because we don't get bored... If we learn in the classroom, we feel sleepy> (Pupil 2)

\section{Games increased pupils' interaction}

The second theme emerged from the students' interview was that games increased students' interaction. They enjoyed playing with friends, they managed to complete the task faster with the help from their friends and they cooperated as a team to complete the task.

\section{Play with Friends}

When asked why they find games to be interesting, all the four pupils $(100 \%)$ stated that games allowed them to play with their friends and at the same time, they learned new vocabularies. The fact that they had the chance to play with their friends, increased their motivation to learn and improve their vocabulary. For rural pupils, mixing learning and playing became a good strategy for their English language learning. Games were found to increase the pupils' interaction. Pupils 1, 2and 3 stated that they could play with their friends while completing the 
games such as guessing pictures (Pupil 2) and competing for riddles (pupil 3). They reported,

Emmmm...Buleh main nga saing2. $<$ Can play with my friends $>$ (Pupil 1)

Kito suko bilo buleh main nga saing...pahtu bleh main teko-teko gambar $<$ We like it because we can play it with our friends and then we can guess the pictures $>$ (Pupil 2)

Buleh jawab teka teki teacher buwi nga main sekali nga saing $<$ I can answer the riddles the teacher gave with my friends $>$ (Pupil 3)

Best..sebab buleh main nga saing-saing... $<$ Best because can play with friends $>$ (Pupil 1)

aaaa...bleh nyanyi ramai-ramai nga saing pahtu wak gayo. $<$ Yes, can sing together with friends and act out $>$ (Pupil 2)

Throughout the activity, I can see that the pupils can work together with their friends. (Teacher B)

All the respondents stated that games enabled them to enjoy playing with their friends. Instead of having a normal lesson in class, they could have outdoor activities together with the peers.

\section{Games help the pupils to improve their English vocabulary}

The results of pre - test and post - test showed the increase in vocabulary scores among the samples after the intervention.

\section{Completing Task}

The students reported that they managed to complete the task faster with help from their peers. By completing the tasks, showed that the games helped them in acquiring new English vocabulary. In the interviews, the pupils mentioned that they managed to complete the tasks given by the teacher which were matching the pictures and 
answering the riddles correctly. Pupil 1 expressed how excited he was when he managed to finish the task. Pupil 2 explained that he could complete the task with help from others, while pupils $1,2,3$, and 4 mentioned that they managed to finish the task faster. They elaborated,

Table 2

Results of pre - test and post-test

\begin{tabular}{ccc}
\hline Scores & Pre - test & Post - test \\
\hline $10 / 10$ & 0 & 6 \\
$9 / 10$ & 0 & 0 \\
$8 / 10$ & 1 & 7 \\
$7 / 10$ & 1 & 0 \\
$6 / 10$ & 3 & 0 \\
$5 / 10$ & 2 & 4 \\
$4 / 10$ & 2 & 1 \\
$3 / 10$ & 6 & 0 \\
$2 / 10$ & 2 & 0 \\
$1 / 10$ & 1 & 0 \\
$0 / 10$ & 0 & 0 \\
\hline Total number of samples & 18 & 18 \\
\hline
\end{tabular}

Bilo buleh wat tu kea sero suko bena $<$ when we managed to finish, we really like it $>$ (Pupil

Buleh wat sekali blako sapa siap.. pakat-pakat tulong blako $<$ we can complete the task Together..everybody helped $>$ (Pupil 2)

Cepat sero siap gapo teacher suroh. $<$ managed to complete easily what the teacher asked $>$ (Pupil 4)

kijo pon siap cepat $<$ task can be completed $>$ (Pupil 1)

bleh wak siap cepat ayat hok teacher suruh $<$ I can make sentences that teacher instructed $>$ (Pupil 2)

Best sebab jadi cepat siap bulat-bulat perkataan tu. $<$ It's interesting because I can circle the verbs in the word search quickly> (Pupil 3) 
The findings from the interview were supported by their teachers who claimed that students were eager to complete the task and at the same time it provided an opportunity for passive learners to participate as their friends helped them. The teachers reported,

Games help them to teach English vocabulary as through games the pupils seem more eager to complete the task given to them (Teacher 1)

I believe that games can give the chances even to the passive pupils to participate in the activity and they are happy to help their friends to complete the task given (Teacher 2)

In summary, for the completion of the task, all the four respondents answered that they could complete the activities by forming simple sentences and competing with each other enthusiastically. Furthermore, they worked together as a team to accomplish the task given by the teacher.

\section{Cooperation with friends}

All the respondents claimed that they could cooperate well in group activity especially when they were asked to find the verbs in the giant word search and constructed simple sentences based on the verbs they have identified earlier. They showed great teamwork in groups and their friends were very helpful and cooperative in completing the task. Pupil 1 said that they could find the words faster because their friends worked together, while Teacher D mentioned that he could make sentences because his friends helped him.

cari perkataan cepat sebab saing tolong wak sekali. $<I$ can find the verbs faster

because my friends help me> (Pupil A)

saing-saing etek tolong wak samo-samo $<$ my friends helped a lot $>$ (Pupil B)

saim kito tolong maso wak ayat tu. $<$ My friends helped me to form the sentences $>$ (Pupil D) 
When it comes to answering riddles, they could do the task because they helped one another and they discussed it with their friends. They elaborated,

sebab saing tulong jawab teka-teki $<$ because my friends help me in answering the riddles $>$ (Pupil 1)

Buleh main ramai2 sekali $<$ can play together $>$ (Pupil 2) Sebab kito mene tadi, buleh wak siap cepat teka teki mugo saing tulung jugok < because we won just now. We finished early the riddles as my friends also helped in solving it $>$ (Pupil 2)

Sebab saing tulung maso nok jawab teko teki tu..jadi sene la sebab buleh bice <because my friends help me when I tried to answer the riddles so it was easier to solve it because we can discuss $>$ (Pupil 4)

This was supported by their teachers who reported that the pupils cooperated well during the task and they helped one another.

they cooperated well in the groups. (Teacher A)

they help each other. (Teacher B)

\section{Singing along in certain part of the games helped pupils to memorise the words (vocabulary)}

Concerning remembering the words learned, the pupils agreed that the games could help them retain their memory for a longer time. The findings indicated that their memory retention was longer as a result of singing along, acting out the words in the songs in a certain part of the games cycle. Pupils 1, 2 and 4 reported that it was easy for them to remember the words because they sang the song together. In addition, Pupil 3 mentioned that she could finish the task (circle the word) faster because she could remember the song and its actions. They reported,

jadi sene ingat sebab nyanyi td <easier to remember (the verbs) because I sang it just now.> (Pupil A) 
Best..best sebab jadi sene ingat perkataan dale lagu tu.. pahtu nok cari perkataan dale manila kad tu pon sene jah sebab ingat hok nyanyi tadi. $<$ It's easy to remember the word in the song..searching the word in the manila card is also easy because I sang it just now > (Pupil B)

Best sebab jadi cepat siap bulat-bulat perkataan tu mugo kito nyanyi keh pahtu wak gayo..jd sene ingat. <It's fun because I can complete the word search quickly circle the words because I sang the song and after that acted it out...becomes easy to remember $>$ (Pupil C)

kito jadi mudoh ingat maso nok wak ayat tu sebab kito nyanyi ramai-ramai takdi. <we can remember the words easily when we want to make the sentence because we sang together with friends $>$ (Pupil D)

This was supported by Teacher A who claimed that her students could remember the words better through songs. She said,

they can remember better the verbs used in the songs. (Teacher A)

\section{Games promoted competition}

The element of competitiveness was also evident in the interview findings. Two students reported that they competed with their friends to see who could finish earlier and the other one competed against each other to step on the bricks. They mentioned,

Buleh main ramai-ramai nga belawe nga saing badi siap cepat. $<$ I can play with my friends and compete with them $>$ (Pupil C)

Main nga saing-saing pahtu buleh lawe saing-saing pijok bato $<$ Play with my friends and then can compete stepping on the bricks with my friends $>$ (Pupil 4)

Similarly, their teacher reported that, as a result of the competitiveness, students managed to complete the task. Teacher B explained,

(students) manage to complete the task given (Teacher B) 


\section{DISCUSSION}

This study was set to examine the use of games in vocabulary learning among ESL rural students. Data were collected using multiple methods such as interviews, observation and pre and post tests and analysed thematically. 18 students were given pre and post vocabulary tests before and after the implementation of games and songs and the results showed that there was an increase in the vocabulary scores with six pupils achieving the highest scores. This indicated that games provided a positive improvement to students' vocabulary. From the interviews conducted on four pupils and two teachers, four themes were highlighted: Games were fun and interesting, they boosted pupils' motivation; they helped pupils to memorise the words (vocabulary) faster, and they increased pupils' interaction.

Student motivation to learn is a chief contributor to student learning outcomes and student persistence in school. Through the interviews and observation, we could see the pupils enjoyed playing the games, they were more relaxed in completing the task and they cooperated well to fulfill the task. They also had fun singing to complete the task. All the pupils were very motivated throughout the lesson and participated actively. Through the interview, all the pupils stated that the game made them feel more motivated to learn English and claimed that they improved their vocabularies. The pupils stated that the game was interesting, gave them the chance to play with their friends, and also provided an opportunity to learn outside the classroom. This is in line with Kyriacou (2001, p.23) who pointed out that, “..... activities must elicit and sustain pupils' attention, interest, and motivation". Even though most of the pupils stated their interest in fun learning activities while playing games, they did not realize that they mastered their vocabulary learning implicitly. These findings also resonate with earlier studies (Freeman, 1986; Taheri, 2014). We have shown evidence that games provided a motivational climate for students' learning (Lightbrown and Spada,1999; Moon, 2000). Therefore, teachers have to play a major role in enhancing the improvement of vocabulary learning and know how to modify teaching and learning based on pupils' needs.

The competitive and repetitive nature of the game helped vocabulary retention (Thornbury, 2002; Mcpherson, 2015; Capar and Tarim, 2015). 
Thornbury (2002) claimed that "The more decisions the learners make about a word, and the more cognitively demanding these decisions, the better the word is remembered" (p.25). After implementing the game, it seemed that the pupils' ability to acknowledge and memorise the words was better. They could easily recall the words and scored well in the post - test. This was because while playing the game, the pupils recognised the pictures and decided on which words belong to the correct pictures. It is clearly shown that when the pupils discovered and acquired the knowledge by themselves, they could remember the words better. On the other hand, the integration of songs contributed a positive effect on the pupils' vocabulary. The longer memory retention of the pupils could be enhanced when songs were included in the game. They were able to construct simple sentences based on the verbs listed in the song. This was because they were having fun remembering and recalling the action, while singing and listening to the song, as part of engaging in the games. By doing so, they managed to work collaboratively with their peers and construct simple sentences. Their teamwork and competitive spirit have resulted in an active learning environment. Using games helped the pupils including the shy ones to interact with each other and this is in line with the study proposed by Moon (2000, p.23) who stated that "(interaction) is the main source of language input". Based on the observation, we could see the good pupils tried their best to help the weaker ones to understand the meaning of the words and how they did their best to communicate to each using L1 and L2 while matching words to the pictures. No doubt, games promoted collaborative learning among the pupils (Macpherson, 2015; Capar and Tarim, 2015).

\section{REFLECTION AND IMPLICATION}

This action research showed that teachers need to vary their teaching techniques to ensure the success of teaching and learning to suit the needs of their pupils. This action research has also benefited us as 'teacher-researchers' where we could understand the needs of our learners. We learned to select the materials appropriate for the cultural context of our learners. Song selection to be included in the games plays a crucial role. The pace of the chosen song should be appropriate for the learners' level of language and the message depicted in the 
song should also be given careful attention (Kuśnierek, 2016). We also learned to create a comfortable, supportive learning environment for ESL learners in our context of the study. During the research, we believe that teachers need to be able to modify the lesson to make sure the pupils can derive the vocabulary learned from the lesson.

The competitive nature of the game made us realized that a teacher can increase students' perception of self-efficacy, thus elevating the students' effort, persistence, and ultimate level of performance by (1) encouraging students to set goals that are specific, challenging, but attainable, (2) modeling effective responses to tasks, (3) providing feedback that encourages students to stay on course until mastery is achieved, and (4) making attributional statements that help students understand and appreciate that they are improving their abilities by accepting challenges and maintaining effort (Bandura, 1997). The improvisation that has been made during the intervention of the cycle which was stimulating the vocabulary learning by introducing some songs gave a big impact as six pupils achieved high scores compared to null during the pre test. We believe that our action research is very useful and can be practised by English teachers in any ESL context.

\section{CONCLUSION}

In conclusion, games are inevitably an effective and interactive way to teach English vocabulary. It promotes active participation from the pupils and boosts up their confidence to use the language to interact with their peers. Considering that vocabulary is a basic skill in the English language, especially for beginners with limited English, teachers may need to use various techniques in teaching. Our study has provided evidence that games can become useful tools in teaching vocabulary to limited proficiency learners as they can show their performance in improving the vocabulary learned. Apart from that, the use of collaborative learning fostered through games should not be neglected by teachers. Brown (2001), argues that the learning experience can be enhanced when there is a collaboration among learners. When learners are engaged in collaborative activity, they learn interpersonal communication skills, they become more considerate of others' feelings, and they develop self-efficacy. Games 
not only improve knowledge, memorization, and usage, but they also promote motivation, relaxation, and self-confidence (Darfilal, 2015).

\section{ACKNOWLEDGMENT}

This research received no specific grant from any funding agency in the public, commercial, or not-for-profit sectors.

\section{REFERENCES}

Burhayani. (2013). The Effectiveness of Teaching Vocabulary through Songs to the Second Years Students of Ikatan Keluarga Kesejahteraan Tentara (IKKT) Elementary School W e $\quad s \quad t$ Jakarta 2nd International Seminar on Quality and Affordable Education (ISQAE 2013)

Ismail, N. S., Zaid, S. B., Mohamed, M. H., \& Mohd Rouyan, N. (2017). Vocabulary Teaching and Learning Principles in Classroom Practices. SSRN Electronic Journal, 8(September), 119-134.

https://doi.org/10.2139/ssrn.3053561

Tengku Mohamad Maasum, T.N. R., Mustaffa, R., \& Stapa, S.H.(2015). YoungLearners'PerceptionsofLearningEnglishUsingLanguage Games in a Non - Formal Context. Mediterranean Journal of Social Sciences, 6(6), 375-382. https://doi.org/10.5901/ mjss.2015.v6n6s5p375

Fitri Mohamad, Luca Morini, Jacey-Lynn Minoi, \& Sylvester Arnab. (2018). ECGBL 2018 12th European conference on game-based learning. Google Books.https://books.google.com.my/books?h $1=$ en $\& 1 \mathrm{r}=\& \mathrm{id}=3 \mathrm{n} 91 \mathrm{DwAAQBAJ} \& \mathrm{oi}=\mathrm{fnd} \& \mathrm{pg}=\mathrm{PA} 433 \& \mathrm{dq}=\mathrm{fi}$ tri + mohamad+et.al\&ots $=j$ RyfTPnz_P\&sig $=0$ SadWe6rOhhQR Lf1m6vb hn7OwQ4\&redir_esc=y\#v=onepage\&q=fitri $\% 20$ mohamad\%20et.al\&f=false

Brown, B.L. (2001) Web-based training. ERIC Digest. (online digest) http://www.ericdigests.org/2001-2/training.html 12 August 2013.

Capar, G., \& Tarim, K. (2015). Efficacy of the Cooperative Learning Method on Mathematics Achievement and Attitude: A MetaAnalysis Research. Educational Sciences: Theory \& Practice. doi:10.12738/estp.2015.2.2098 
Creswell, J.W. (2013). Qualitative Inquiry and Research Design: Choosing among five approaches. Thousand Oaks: Sage Publications.

Coady, J. \& Huckin, T. (1997). Second language vocabulary acquisition. Cambridge: Cambridge University Press.

Darfilal, I. (2015) The Effectiveness of Using Language Games in Teaching Vocabulary. The Case of Third Year Middle School Learners_http://dspace.univtlemcen.dz/ bitstream/112/7872/1/darf.pdf

Dzanic, N. D., \& Pejic, A. (2016). The effects of using songs to young learners and their motivation for learning English.

Esterman, K. and Hedlund, D. (1995). Comparing rural adolescents from farm and nonfarm families. Journal of Research in Rural education, 11,84-91.

Gasma, Y., Yufrizal, H., \& Sukirlan, M. (2016). Teaching vocabulary through song at the first grade of senior high school fkip University of Lampung

Harmer, J. (1991). The practice of English Language Teaching. London: Longman.

Hatch, E. and Brown, C. (1995). Vocabulary, semantic and language education. Cambridge: Cambridge University Press.

Holden, W.R. (1999). Learning to learn 15 vocabulary acquisition activities. Modern English Teacher, 8(2), 42-47.

Kyriacou, C. (2001). Essential teaching skills. Cheltenham, UK: Nelson Thorne.

Kuśnierek, A (2016) The Role of Music and Songs in Teaching English Vocabulary to Students, World of Scientific Science WSN 43(1) (2016) 1-55 EISSN 2392-2192

Macpherson, A. (2015). Cooperative Learning Group Activities for College Courses. Kwantlen Polytechnic University

Moon, J. (2000). Children Learning English. London: Macmillan.

Nation, I.S.P. (1990). Teaching and Learning Vocabulary. New York: Newbury House.

Nyugen and Khuat. (2003). Learning vocabulary through games. Asian EFL Journal._http://www.asian-efl-journal.com/dec-03sub.Vn.php

Perveen, A., M., Mehmood, S., Khan, M., \& Z. (2016). Effectiveness of language games in second language vocabulary acquisition. Sci.Int. (Lahore), 28(1), 633-637. Retrieved March 1, 2018. 
Ralph, E. (2006). Promoting Teaching in Rural Schools. Journal of Teaching and Learning,2(2).doi:10.22329/jtl. v2i2.106

Rivers, W. (1981). Teaching Foreign language skills. Chicago: The University of Chicago.

Richard-Amato, P. (1988). Making it happen: Interactions in the second language classroom. New York: Longman.

Sigurðardóttir, S. (2010). The use of games in the language classroom. [online] Available at: https://skemman.is/bitstream/1946/6467/1/ Sigridurdogg2010.pdf [Accessed 7 Aug. 2018].

Šišková, D. (2008). Teaching Vocabulary through Music. Masaryk University in Brno Faculty of Education

E. Slavin, R. (2014). Cooperative learning in elementary schools. doi:https://doi.org/10.1080/03004279.2015.963370

Smith, H. (2018). Incorporating Multiple Intelligences Within Instructional Strategies. Retrieved from http://digitalcommons. uri.edu/srhonorsprog

Smith, M.H., Beaulieu, L.J. and Seraphine, A. (1995). Social capital, place of residence and college attendance. Rural sociology, 60,363-380.

Taheri, M. (2014). The effect of using language games on vocabulary retention of Iranian elementary ELF learners. Journal of Language Teaching and Research,5(3), 544-549. doi:10.4304/ jltr.5.3.544-549

Thornbury, S. (2002). How to Teach Vocabulary. London: Longman. February15, 2008, from http://www.pearsonlearning.com/ communities/assets/research_center/ResearchPaper_ VocabWorks.pdf.

Saif Al-Kalbani, M., \& SalehAl-Wahaibi, S. (2015). Testing the Multiple Intelligences Theory in Oman. doi:https://doi. org/10.1016/j.sbspro.2015.10.001 Proceedings of 2nd global.

Uberman, A. (1998). The use of games for vocabulary presentation and revision. English Teaching Forum, 36 (1), 253-285. 